WenDell VILAS BOAS ${ }^{1}$

Rozana Oliveira Gonçalves ${ }^{2}$

Olívia LÚCia Nunes COSTA ${ }^{3}$

MARILDA SOUZA GONCALVES ${ }^{1}$

\title{
Metabolism and gene polymorphisms of the folate pathway in Brazilian women with history of recurrent abortion
}

\author{
Metabolismo e polimorfismos gênicos da via do folato em \\ mulberes brasileiras com história de aborto recorrente
}

Artigo Original

Palavras-chave

Acido fólico

Homocisteína

Polimorfismos gênicos

Aborto habitual

Vitamina B 12

Keywords

Folic acid

Homocysteine

Polymorphisms, genetic

Abortion, habitual

Vitamin $B_{12}$
Abstract

PURPOSE: To investigate the association between polymorphisms in genes that encode enzymes involved in folate- and vitamin B 12 -dependent homocysteine metabolism and recurrent spontaneous abortion (RSA). METHODS: We investigated the C677T and A1298C polymorphisms of the methylenetetrahydrofalate reductase gene (MTHFR), the A2756G polymorphism of the methionine synthase gene (MS) and the 844ins68 insertion of the cystathionine beta synthetase gene (CBS). The PCR technique followed by RFLP was used to assess the polymorphisms; the serum levels of homocysteine, vitamin $B_{12}$ and folate were investigated by chemiluminescence. The EPI Info Software version 6.04 was used for statistical analysis. Parametric variables were compared by Student's t-test and nonparametric variables by the Wilcoxon rank sum test. RESULTS: The frequencies of gene polymorphisms in 89 women with a history of idiopathic recurrent miscarriage and 150 controls were 19.1 and $19.6 \%$ for the C677T, insertion, 20.8 and $26 \%$ for the A1298C insertion, 14.2 and $21.9 \%$ for the A2756G insertion, and 16.4 and $18 \%$ for the 844 ins 68 insertion, respectively. There were no significant differences between case and control groups in any of the gene polymorphisms investigated. However, the frequency of the 844 ins68 insertion in the CBS gene was higher among women with a history of loss during the third trimester of pregnancy ( $p=0.003$ ). Serum homocysteine, vitamin $B_{12}$ and folate levels id not differ between the polymorphisms studied in the case and control groups. However, linear regression analysis showed a dependence of serum folate levels on the maintenance of HHcy levels. CONCLUSION: The investigated gene polymorphisms and serum homocysteine, vitamin $B_{12}$ and folate levels were not associated with idiopathic recurrent miscarriage in the present study. Further investigations are needed in order to confirm the role of the CBS 844ins68 insertion in recurrent miscarriage.

\section{Resumo}

OBJETIVO: Investigar a associação entre polimorfismos nos genes que codificam enzimas envolvidas no metabolismo da homocisteína dependente de folato e vitamina B12 e aborto espontâneo recorrente. MÉTODOS: Investigamos os polimorfismos C677T e A1298C no gene methilenotetrahidrofalato redutase (MTHFR); o polimorfismo A2756G no gene metionina sintase (MS) e a inserção 844ins68 no gene da cistationina beta-sintetase (CBS). A técnica de PCR seguido por RFLP foi utilizada para investigar os polimorfismos. Os níveis séricos de homocisteína, vitamina B 12 e de folato foram investigados pela técnica de quimioluminescência. O Software Epi Info versão 6.04 foi utilizado para realizar a análise estatística. As variáveis paramétricas foram comparadas pelo teste t de Student e as variáveis não paramétricas pelo teste de Wilcoxon rank sum. RESULTADOS: As frequências dos polimorfismos gênicos em 89 mulheres com história de aborto recorrente idiopático e 150 controles foram de 19,1 e 19,6\% para o C677T; 20,8 e 26\% para o A1298C; 14,2 e $21,9 \%$ para o A2756G e 16,4 e 18\% para a inserção 844ins68, respectivamente. Não houve diferenças significantes entre os grupos caso e controle em todos os polimorfismos dos genes investigados. No entanto, a frequência da inserção 844 ins 68 no gene CBS foi maior entre mulher com histórico de perdas no terceiro trimestre da gravidez $\mathrm{p}=0.003$ ). Os níveis de homocisteína, vitamina B 12 e folato séricos não foram diferentes entre os polimorfismos estudados nos grupos casos e controles. No entanto, a análise de regressão linear mostrou dependência dos níveis séricos de folato na manutenção dos níveis de homocisteína. CONCLUSÃO: Os polimorfismos gênicos investigados, assim como homocisteína, vitamina B1 2 e os níveis séricos de folato não foram associados com abortos recorrentes idiopático no presente estudo. Novas investigações devem ser realizados a fim de confirmar o papel da inserção 844ins68-CBS nos abortos recorrentes.
Correspondence

Marilda Souza Goncalves Goncalo Moniz Research Center/FIOCRUZ Rua Waldemar Falcão, 121 - Brotas Zip code: $40295-001$

Solvador (BA), Brozil

Received

$11 / 24 / 2014$

Accepted with modification

$12 / 03 / 2014$
Laboratório de Hematologia, Genética e Biologia Computacional, Centro de Pesquisas Gonçalo Moniz, Fundação Oswaldo Cruz FIOCRUZ - Salvador (BA), Brazil.

'Centro de Pesquisas Gonçalo Moniz, Fundação Oswaldo Cruz - FlOCRUZ - Salvador (BA), Brazil.

2Programa de Pós-graduação em Biotecnologia em Saúde e Medicina Investigativa, Centro de Pesquisas Gonçalo Moniz, Fundação Oswaldo Cruz - FIOCRUZ - Salvador (BA), Brazil.

3Departamento de Ginecologia e Obstetrícia, Universidade Federal da Bahia - UFBA - Salvador (BA), Brazil.

Conflict of interests: none. 


\section{Introduction}

Folate is essential for normal DNA and RNA biosynthesis and it is required for homocysteine metabolism. It appears obvious that folate is essential for normal fetal development, and during pregnancy, women have an increased physiological need for this vitamin ${ }^{1}$.

Homocysteine (tHcy) is a sulphur-containing intermediate in methionine metabolism, which can be catabolized in the transsulphuration pathway (vitamin B6-dependent) or remethylated to methionine (folate- and cobalamin-dependent $)^{2}$. Two main factors affect homocysteine concentration in humans: diet, specially the intake of folate and vitamin B12, and polymorphism in genes which encode enzymes or transport proteins involved in the folate- and vitamin B12-dependent homocysteine metabolism ${ }^{3,4}$.

The dietary intake of essential micronutrients determines the efficiency of homocysteine metabolism in general, and the reduction in the dietary intake of $\mathrm{B}$ complex vitamins such as folate, B6 and B12 leads to an increase in the levels of plasma homocysteine ${ }^{5,6}$. The MTHFR gene polymorphisms are commonly associated with hyperhomocysteinemia ${ }^{7,8}$. The best characterized MTHFR gene polymorphism consists of a $677 \mathrm{C}$ to $\mathrm{T}$ transition, which results in an alanine to valine substitution in the predicted catalytic domain of the enzyme. This is a risk factor for neural tube defects and recurrent embryo loss in pregnant women ${ }^{9,10}$. A second prevalent gene polymorphism which is associated with the in-vitro decrease of the enzyme activity is an A to C transversion at nucleotide 1298, resulting in a glutamine to alanine substitution in the enzyme molecule. Although it has been shown that the A1298C gene polymorphism, in either heterozygousity or homozygousity, is not associated with higher plasma tHcy concentrations, combined heterozygousity of the C677T and A1298C polymorphisms is associated with reduced MTHFR specific activity and higher tHcy concentrations when compared with heterozygosity for either varian ${ }^{11}$. Other enzymes, such as methionine synthase (MS), also play an important role in homocysteine metabolism; and its activity reduction due to A2756G polymorphism or inadequate cofactor (vitamin B12) concentrations may result in elevated homocysteine levels ${ }^{12}$. On the other hand, the cystathionine beta-synthetase (CBS) catalyzes the condensation of serine and homocysteine in order to form cystationine, and abnormality in CBS activity is manifested in two clinical conditions: hyperhomocysteinemia and homocystinuria ${ }^{13}$. The 844 ins 68 insertion of the CBS gene, apparently, does not cause a decrease of enzyme activity, but the allele carriers have an impaired gene transcription ${ }^{14}$. Several complications in pregnancy have been attributed to hyperhomocysteinemia, such as neural tube defects, pre-eclampsia and recurrent pregnancy loss $9,10,15$.

The aim of this study was to investigate polymorphisms in genes that encode enzymes involved in folateand vitamin B12-dependent homocysteine metabolisms, such as C677T and A1298C in the MTHFR gene, the A2756G in the MS gene and the 844ins68 insertion in CBS gene in a group of women with recurrent pregnancy loss and in a group of women that comprised the controls, investigating its association with serum levels of vitamin B12, folate and homocysteine.

\section{Methods}

\section{Subjects}

We performed a case-control study in order to investigate the association between polymorphisms in genes that encode enzymes involved in folate- and vitamin $\mathrm{B}_{12}$-dependent homocysteine metabolism and recurrent spontaneous abortion (RSA). The study included 89 women with at least two consecutive miscarriages in the first, second or third trimester of gestation, without any successful pregnancy. Abortion diagnoses were identified by hCG testing, ultrasound, and/or physical examination. The patients were recruited at the Department of Obstetrics and Gynecology of Maternidad Climério de Oliveira, in Salvador, Bahia, Brazil. The cases were identified and selected when they visited the above mentioned hospitals for investigation of two or more consecutive unexplained terminations of pregnancy. All patients underwent a complete diagnostic work-up for RSA, including screening for hypertension, chronic infections, anatomical disorders, antiphospholipid syndrome, inherited thrombophilia, thyroid dysfunction and diabetes mellitus. Of 89 cases, $90 \%$ of RSA women were supplemented with folic acid ( 3 months before pregnancy and 3 months of pregnancy, $5 \mathrm{mg}$ each day). RSA patients who were over 40 years of age and had previous live births were excluded from this study.

The control population consisted of 150 healthy women of similar age to the patients', with at least one live born child and no history of pregnancy loss. These women were selected during their post-partum in the maternity ward of the Tsylla Balbino. The Cases and controls came from a public hospital, so that both groups had similar socioeconomic status to search for genetic polymorphisms. Out of the 89 women with recurrent miscarriage, 46 of them were tested for vitamin B12, folate and homocysteine levels and compared with 47 controls. A questionnaire was filled out by each patient to record the details of their lifestyle, habits, and family history.

All participating subjects personally provided their consent to participate in the study. 
Biochemical and Molecular analysis

Blood samples were drawn from women using sterile tubes with anticoagulant (EDTA) and sterile tubes without additive. Serum samples were separated and kept frozen at $-20^{\circ} \mathrm{C}$ until the analysis was performed.

The folate and vitamin B12 serum levels were measured by immunochemiluminescence immunoassay, by Access 2 Immunoassay System (Beckman Couter, CA - USA) device, according to manufacturer's instructions. The tHcy serum levels were measured by chemiluminescence immunoassay by an automatic device, IMMULITE 2000, according to manufacturer's instructions.

The DNA was isolated from leukocytes using a Qiagen DNA Mini Kit. Genotype analyses of the polymorphisms were performed by PCR followed by RFLP analyses, except for the CBS 844ins68 insertion - which was only performed by PCR technique. The primers sequence and PCR conditions used were as previously described for MTHFR C677T polymorphism ${ }^{7}$; MTHFR A1298C polymorphism ${ }^{11}$; MS A2756G polymorphism ${ }^{16}$ and CBS 844 ins 68 insertion $^{17}$.

\section{Statistical Analysis}

The EPI Info Software, version 6.04 was used for the statistical analysis. Parametric variables were compared by Student's $t$-test and nonparametric variables by the Wilcoxon rank sum test. The Software SPSS, version 9.0, was used for the linear regression analysis. The tHcy serum level was considered as a dependent variable and folate and vitamin B12 serum levels were the independent variables. A p-value of $>0.05$ was considered statistically significant. The Hardy-Weinberg equilibrium was applied in order to estimate the equilibrium of gene polymorphisms frequency distributed between cases and control groups.

\section{Ethical Standards}

The study was approved by the Human Ethics Committee of Oswaldo Cruz Research Foundation. The protocol and procedures presented in the project are in accordance with the ethical standards of the responsible committee on human subjects and the Helsinki Declaration of 1964 , as revised in 2008.

\section{Results}

\section{Demographic data}

The median age of the 89 women in the study group was $29.4( \pm 5.4)$ years of age, ranging from 17 to 40 years old, and the control group aged $23( \pm 5.5)$ years old. The median abortion number in the study group was $3.2( \pm 1.9)$, ranging from 2 to 13 abortions, in which 41 (47\%) women had two spontaneous abortions; 25 (29\%) of them had three spontaneous abortions, and $21(24 \%)$ of them had more than three abortions.

The gestational age, when the abortions occurred, was divided into first, second or third trimester and mixed when there were intersessions between them. Our data show that in $29(33 \%)$ women, the abortion occurred in the first trimester; $22(25 \%)$ of them in the second trimester; $8(9 \%)$ of them in the third trimester, and $28(32 \%)$ women were included in the mixed abortion group, because they presented these events at different times during their pregnancies.

Obstetric complications presented in the study group included 4 women with pre-eclampsia (8.5\%); 7 with high blood pressure (16\%) and 5 with cervical incompetence (10.6\%). In the control group, there were 8 women $(5.6 \%)$ who had a pre-eclampsia event.

The frequency of smoking in the study group was $2 \%$ (1/47), and 42.6\% (20/47) had drunk some alcoholic beverage once a week when they were not pregnant. The frequency of smoking in the controls group was higher than in the study group, $12.6 \%$ (19/150), showing statistical difference $(\mathrm{p}=0.02)$. Twenty six $(17 \%)$ women in the control group drank some alcoholic beverages during pregnancy.

Fifty-nine percent (28/47) of the women who comprised the case group had three daily meals. The most frequent combination of food was rice, beans and meat in $59.6 \%$ $(28 / 47)$ of the cases. The ingestion of food-containing fat was observed in $74.5 \%(35 / 47)$ of this group. However, a salad was included in the meal of $89.4 \%(42 / 47)$ of women, varying from 1 to 4 times a week.

\section{Gene polymorphisms distribution}

We determined the MTHFR C677T and A1298C genotypes in 89 women with recurrent spontaneous abortions and 150 controls (Table 1). The frequencies of the

Table 1. Frequencies of the polymorphisms of the enzymes MTHFR, MS and CBS gene between women with recurrent miscarriage and controls

\begin{tabular}{|c|c|c|c|c|c|c|c|c|}
\hline & \multicolumn{2}{|c|}{ Wild Type } & \multicolumn{2}{|c|}{ Heterozygous } & \multicolumn{2}{|c|}{ Homozygous } & \multicolumn{2}{|c|}{ Total } \\
\hline & Study & Control & Study & Control & Study & Control & \multirow{2}{*}{ Study } & \multirow{2}{*}{ Control } \\
\hline & $n(\%)$ & $n(\%)$ & $n(\%)$ & $n(\%)$ & $n(\%)$ & $n(\%)$ & & \\
\hline C677T - MTHFR & 59 (66.3) /CC & $97(65) / C C$ & $26(29) / \mathrm{CT}$ & $47(31) / C T$ & $4(4.5) / \mathrm{TT}$ & $6(4) / \pi$ & 89 & 150 \\
\hline A1298C - MTHFR & 57 (64) /AA & $80(53.4) / A A$ & $27(30.4) / A C$ & $62(41) / A C$ & $5(5.6) / C C$ & $8(5.3) / C C$ & 89 & 150 \\
\hline$A 2756 G-M S$ & 65 (74) /AA & $92(61.4) / A A$ & $21(24) / A G$ & $50(33) / A G$ & $2(2.3) / G G$ & $8(5.3) / G G$ & 89 & 150 \\
\hline 844ins68 - CBS & 62 (70.5) /WW & 103 (69) /WW & $23(26) / W I$ & $40(26.6) / \mathrm{WI}$ & $3(3.4) / 11$ & $7(4.7) / 11$ & 89 & 150 \\
\hline
\end{tabular}

W: Wild type; I: Insertion 
Table 2. Distribution of the CBS 844ins68 insertion in the case group and gestational age when the miscarriages occurred

\begin{tabular}{lcccc}
\hline \multirow{2}{*}{$\begin{array}{l}\text { Gestational } \\
\text { age }\end{array}$} & \multicolumn{3}{c}{ 844ins68 insertion genotype } & \\
\cline { 2 - 4 } & $\begin{array}{c}\text { Wild type } \\
\text { n (\%) }\end{array}$ & $\begin{array}{c}\text { Heterozygous } \\
\text { n (\%) }\end{array}$ & $\begin{array}{c}\text { Homozygous } \\
\text { n (\%) }\end{array}$ & Total \\
\hline $1^{\circ}$ Trimester & $22(78.5)$ & $6(21.4)$ & 0 & 28 \\
$2^{\circ}$ Trimester & $16(72)$ & $6(27)$ & 0 & 22 \\
$3^{\circ}$ Trimester & $5(62.5)$ & $1(12.5)$ & $2(25)$ & 8 \\
Mixed & $19(68)$ & $8(28.5)$ & $1(3.5)$ & 28 \\
Total & $62(72)$ & $21(24.5)$ & $3(3.5)$ & 86 \\
\hline
\end{tabular}

$\chi^{2}=13.53 ; p=0.03$

Table 3. Homocysteine serum levels among women with recurrent miscarriage, according to genotypes of each polymorphism

\begin{tabular}{lllll}
\hline \multirow{2}{*}{ Polymorphisms } & \multicolumn{5}{c}{ Genotypes } \\
\cline { 2 - 5 } & \multicolumn{1}{c}{ Wild type } & Heterozygous & Homozygous & p-value \\
\hline MTHFR & & & & \\
C677T & $(35 / 46) 4.9 \pm 1.5$ & $(9 / 46) 4.8 \pm 2.5$ & $(2 / 46) 4.6 \pm 0.91$ & $0.96^{\star}$ \\
A1298C & $(27 / 46) 4.8 \pm 1.1$ & $(15 / 46) 5.2 \pm 2.0$ & $(4 / 46) 3.8 \pm 0.76$ & $0.23^{\star \star}$ \\
MS & & & & \\
$\begin{array}{c}\text { A2756G } \\
\text { CBS } \\
\text { 844ins68 }\end{array}$ & $(37 / 46) 4.9 \pm 1.6$ & $(8 / 46) 4.55 \pm 0.9$ & $(1 / 46) 6.2$ & $0.45^{\star}$ \\
\hline
\end{tabular}

*Kruskal-Wallis; **Anova.

Table 4. Homocysteine serum levels of control group according to genotypes of each polymorphism

\begin{tabular}{|c|c|c|c|c|}
\hline \multirow{2}{*}{ Polymorphisms } & \multicolumn{4}{|c|}{ Genotypes } \\
\hline & Wild type & Heterozygous & Homozygous & $\mathrm{p}$-value \\
\hline \multicolumn{5}{|l|}{ MTHFR } \\
\hline C677T & $(29 / 47) 6.2 \pm 2.4$ & 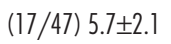 & (1/47) 11.2 & $0.22^{\star}$ \\
\hline Al298C & $(31 / 47) 6.1 \pm 2.3$ & (14/47) $6.3 \pm 2.6$ & $(2 / 47) 5.6 \pm 2.2$ & $0.89 *$ \\
\hline \multicolumn{5}{|l|}{ MS } \\
\hline A2756G & $(32 / 47) 6.24 \pm 2.5$ & (14/47) $6.2 \pm 2.2$ & (1/47) 3.7 & $0.35^{\star}$ \\
\hline CBS & & & & \\
\hline 844 ins 68 & $(29 / 47) 6.01 \pm 2.2$ & (16/47) 6.3 2.2 .4 & $(2 / 47) 7.2 \pm 5.6$ & $0.86^{*}$ \\
\hline
\end{tabular}

*Kruskal-Wallis.

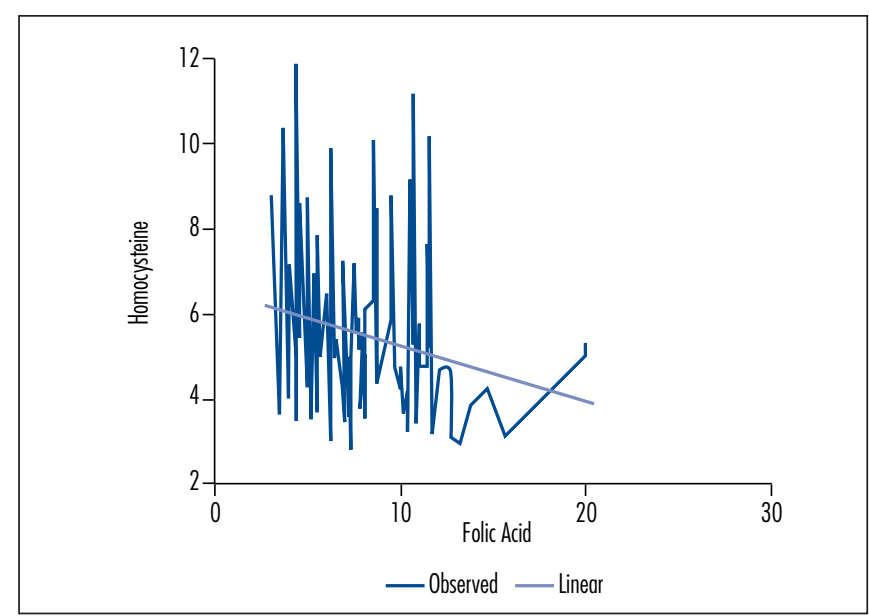

Figure 1. Linear regression analysis of folate $(\mathrm{ng} / \mathrm{mL}$ ) and $\mathrm{tHcy}$ (umol/L) serum levels of the study and control groups, $p=0.03$
T allele of the C677T genotype were 19 and 19.6 in case and control groups, respectively; and the $\mathrm{C}$ allele of the A1298C genotype was 21 and $26 \%$ in case and control groups, respectively. There was no statistical difference among the allele distribution and the genotype frequencies between case and control groups ( $p>0.05)$. A double heterozygote, 677CT/1298AC, was found in this study at frequencies of 8 and $10 \%$ in case and control groups.

The frequencies of the MS A2756G and CBS 844ins68 insertion genotypes between case and control groups are shown in Table 1 . There were no significant differences in the frequency of the genotypes between the studied groups $(\mathrm{p}>0.05)$. However, when we analyzed both the mutant heterozygous and homozygous genotypes together, we found a higher frequency of the mutant genotype of the MS gene in the control group $(\mathrm{p}=0.04)$.

All gene polymorphisms frequencies were in Hardy-Weinberg equilibrium.

The CBS 844ins68 insertion was more frequent in women with recurrent pregnancy loss in the third trimester. The polymorphism investigated was associated with the gestational age when the abortion occurred. There was a significant difference in the distribution of the homozygous genotype between the women with recurrent pregnancy loss (Table 2), which suggested that the homozygous 844 ins 68 was a risk factor for the occurrence of abortion in the third trimester $(\mathrm{p}=0.03)$.

Homocysteine, vitamin B12 and folate serum levels did not differ between the different polymorphism genotypes. Serum from 47 women with recurrent abortion and 47 control ones were tested for homocysteine. The levels were not different between all genotypes investigated, as shown in Tables 3 and 4, respectively.

The relationship between vitamin B12 and folate was also examined in the cases, but there was no association with the gene polymorphisms genotypes (Table 4).

The linear regression analysis of the tHcy and folate serum levels from both groups showed a negative correlation between those variables $(\mathrm{p}=0.03)$ (Figure 1$)$. The same analysis developed between the vitamin B12 and tHcy serum concentration was not significant $(\mathrm{p}=0.58)$.

\section{Discussion}

This is the first study comparing CBS 844ins68 insertion and recurrent abortion. We observed a higher frequency of this insertion among homozygous women and spontaneous recurrent abortion within the third trimester of pregnancy. The most common type of inherited homocystinuria is an autossomal recessive trait related to a genetic deficiency of $\mathrm{CBS}^{18}$, and there are no reports which associate this change with fetal loss. The analysis 
of the C677T and A1298C MTHFR genotypes and the A2756G MS genotype did not show a statistical association with recurrent abortion and gestational age, but we observed a trend related to the A1298C. This indicates the need for additional research involving a larger number of women, once ${ }^{19}$ it was observed the association of MTHFR A1298C polymorphism (but not of MTHFR C677T) with elevated homocysteine levels and placental vasculopathies.

Folate and vitamin B12 play an important role in the homocysteine metabolism; participating in the more frequent pathway, the remetilation. The dietary intake of essential micronutrients determines the efficiency of homocysteine metabolism in general ${ }^{5}$. The intake of these vitamins is essential during pregnancy, and it has been suggested that a greater reduction in risk of pregnancy complications may occur if a combination of folate and vitamin B12 is given ${ }^{20}$.

We investigated the serum levels of folate and vitamin B12 in women with recurrent miscarriage and control groups. The normal value for folate is $>3 \mathrm{ng} / \mathrm{mL}$ and for vitamin B12 is 223 to $1132 \mathrm{pg} / \mathrm{mL}$. Our data show that there was no vitamin deficiency in either group, even when it was categorized into different genotypes of the polymorphisms investigated. However, the analysis of linear regression showed a dependence of folate serum levels in the maintenance of the levels of tHcy, as previously described ${ }^{3}$. As the fetal loss is a multifactorial problem, supplementation of folate and vitamin B12 will reduce the risk of abortion caused by the deficiency of these micronutrients.

Risk factors such as socioeconomic status, age parity, maternal birth weight, past obstetric outcomes, race, nutrition, smoking, and drug use are thought to be key determinants of the adverse outcome of pregnancy ${ }^{21}$. Our study was undertaken in a public hospital and was comprised of women of low social economic status. The linear correlation between folate and homocysteine levels indicates an involvement of the nutritional status among the studied group. This fact should be considered in that previous work has suggested an association between poor nutritional intake and recurrent miscarriage ${ }^{6,22}$. The finding of a possible role of the cystathionine beta synthetase gene in the fetal-loss group emphasizes a possible contribution of this and other molecules and nutritional status in the homocysteine metabolism and abortion.

The information that the homozygous for C677T transition in the MTHFR gene is associated with the fast increment of plasma tHcy is well known ${ }^{7,20}$. Interestingly, in this study, such association was not shown. This could be due to lack of vitamin deficiency in both groups. In spite of that, the $\mathrm{C} 677 \mathrm{~T}$ thermolabile variant of the MTHFR is an important genetic determinant of tHcy metabolism. Individuals homozygous for the mutant $\mathrm{T}$ allele exhibit increase elevations of the amino acid in their blood in comparison with other genotypes only under conditions of lower folate status ${ }^{6,23}$. This shows that B-vitamin status modifies the relationship between the MTHFR C677T mutation and tHcy serum levels. However ${ }^{24}$, in a crosssectional study, the folate-dependent relation between the MTHFR C677T genotype and plasma tHcy concentration by gender was examined, which showed that, among young women, the MTHFR genotype is not a strong predictor of tHcy levels under diverse conditions of folate status. This data were not confirmed among men.

In the present study, tHcy serum levels were similar between the two groups investigated.

Previous studies had demonstrated a higher frequency of homozygous to the MTHFR C677T genotype and higher tHcy serum levels in women with recurrent miscarriage than in control groups ${ }^{15,22}$. However, Creus et al. ${ }^{6}$ and Pihusch et al. ${ }^{25}$ did not demonstrate such association.

In our study, the frequency of genetic polymorphisms that encode enzymes involved in folate- and vitamin B12-dependent homocysteine metabolism, the MTHFR C677T and A1298C; MS A2756G and CBS 844ins68 insertion, did not show differences in a group of women with recurrent miscarriage and a control group. This is in agreement with Puri et al. ${ }^{15}$ and Zonouzi et al. that investigated the MTHFR polymorphisms in North India and Iran respectively. In contrast, other studies described the relationship between the gene polymorphisms: $\mathrm{MTHFR}^{4,20} ; \mathrm{MS}^{26}$ and recurrent abortion.

However, in the study group, there was an association with a presence of CBS 844ins68 insertion and recurrent abortion in the third trimester. As we are the first to relate the association of the CBS 844ins68 insertion and recurrent abortion, further studies are needed to confirm this finding, as well as its influence in the vitamin-intake levels and fetal loss in different populations with a larger sample.

On the other hand, the inconsistent results between our data and other studies may be attributed to the difference of gestational weeks used to define RSA in each study, the differences in the populations, or due to the small sample size our results weren't able to reach statistical significance.

\section{Acknowledgments}

This study was supported by the CNPq, contract grant number 306524/2004-0 to MSG; FAPESB, contract grant number 1431030005540 to MSG and Brazilian Department of Healthy contract grant number 3111 to MSG. 
1. Milman N, Byg KE, Hvas AM, Bergholt T, Eriksen L. Erythrocyte folate, plasma folate and plasma homocysteine during normal pregnancy and postpartum: a longitudinal study comprising 404 Danish women. Eur J Haematol. 2006;76(3):200-5.

2. Zonouzi AP, Chaparzadeh N, Estiar MA, Sadaghiani MM, Farzadi L, Ghasemzadeh A, et al. Methylenetetrahydrofolate reductase C677T and A1298C mutations in women with recurrent spontaneous abortions in the Northwest of Iran. ISRN Obstet Gynecol. 2012;2012:945486.

3. Zetterberg H. Methylenetetrahydrofolate reductase and transcobalamin genetic polymorphisms in human spontaneous abortion: biological and clinical implications. Reprod Biol Endocrinol. 2004;2:7.

4. Cao Y, Xu J, Zhang Z, Huang X, Zhang A, Wang J, et al. Association study between methylenetetrahydrofolate reductase polymorphisms and unexplained recurrent pregnancy loss: a meta-analysis. Gene. 2013;514(2):105-11

5. De la Calle M, Usandizaga R, Sancha M, Magdaleno F, Herranz A, Cabrillo E. Homocysteine, folic acid and B-group vitamins in obstetrics and gynaecology. Eur J Obstet Gynecol Reprod Biol. 2003; 107(2): 125-34

6. Creus M, Deulofeu R, Peñarrubia J, Carmona F, Balasch J. Plasma homocysteine and vitamin B12 serum levels, red blood cell folate concentrations, C677T methylenetetrahydrofolate reductase gene mutation and risk of recurrent miscarriage: a case-control study in Spain. Clin Chem Lab Med. 2013;51(3):693-9.

7. Frosst $P$, Blom HJ, Milos R, Goyette P, Sheppard CA, Matthews $R G$, et al. A candidate genetic risk factor for vascular disease: a common mutation in methylenetetrahydrofolate reductase. Nat Genet. 1995;10(1):111-3.

8. Robertson L, Wu O, Langhorne P, Twaddle S, Clark P, Lowe GD, et al. Thrombophilia in pregnancy: a systematic review. $\mathrm{Br} J$ Haematol. 2005;132(2):171-96.

9. Blom HJ, Shaw GM, den Heijer M, Finnell RH. Neural tube defects and folate: case far from closed. Nat Rev Neurosci. 2006;7(9):724-31.

10. Mtiraoui N, Zammiti W, Ghazouani L, Braham NJ, Saidi S, Finan RR, et al. Methylenetetrahydrofolate reductase C677T and A1298C polymorphism and changes in homocysteine concentrations in women with idiopathic recurrent pregnancy losses. Reproduction. 2006; 131 (2):395-401.

1 1. Van der Put NM, Gabreëls F, Stevens EM, Smeitink JA, Triibels FJ, Eskes TK, et al. A second common mutation in the methylenetetrahydrofolate reductase gene: an additional risk factor for neural-tube defects? Am J Hum Genet. 1998;62(5):1044-51.

12. Barbosa PR, Stabler SP, Machado AL, Braga RC, Hirata RD, Hirata $M H$, et al. Association between decreased vitamin levels and MTHFR, MTR and MTRR gene polymorphisms as determinants for elevated total homocysteine concentrations in pregnant women. Eur J Clin Nutr. 2008;62(8):1010-21.

13. Dutta S, Sinha S, Chattopadhyay A, Gangopadhyay PK, Mukhopadhyay J, Singh $M$, et al. Cystathionine beta-synthase T833C/844INS68 polymorphism: a family-based study on mentally retarded children. Behav Brain Funct. 2005; 1:25.
14. Tsai MY, Bignell M, Schwichtenberg K, Hanson NQ. High prevalence of a mutation in the cystathionine beta-synthase gene. Am J Hum Genet. 1996;59(6): 1262-7.

15. Puri M, Kaur L, Walia GK, Mukhopadhhyay R, Sachdeva MP, Trivedi SS, et al. MTHFR C677T polymorphism, folate, vitamin B 12 and homocysteine in recurrent pregnancy losses: a case control study among North Indian women. J Perinat Med. 2013;41(5):549-54.

16. Leclerc D, Campeau E, Goyette P, Adjalla CE, Christensen B, Ross $M$, et al. Human methionine synthase: cDNA cloning and identification of mutations in patients of the cblG complementation group of folate/cobalamin disorders. Hum Mol Genet. 1996;5(12): 1867-74.

17. Griffioen PH, de Jonge R, van Zelst BD, Montserrate Brouns R, Lindemans J. Detection and allele-frequencies of the $833 T>C$, 844 ins 68 and a novel mutation in the cystathionine beta-synthase gene. Clin Chim Acta. 2005;354(1-2):191-4.

18. Quéré I, Paul V, Rouillac C, Janbon C, London J, Demaille J, et al. Spatial and temporal expression of the cystathionine beta-synthase gene during early human development. Biochem Biophys Res Commun. 1999;254(1):127-37.

19. Klai S, Fekih-Mrissa N, El Housaini S, Kaabechi N, Nsiri B, Rachdi $R$, et al. Association of MTHFR A 1298C polymorphism (but not of MTHFR C677T) with elevated homocysteine levels and placental vasculopathies. Blood Coagul Fibrinolysis. $2011 ; 22(5): 374-8$.

20. Nair RR, Khanna A, Singh R, Singh K. Association of maternal and fetal MTHFRA $1298 \mathrm{C}$ polymorphism with the risk of pregnancy loss: a study of an Indian population and a meta-analysis. Fertil Steril. 2013;99(5):1311-1318.e4.

21. Rees GA, Brooke ZM, Doyle W. Thiamin status of nulliparous women in the first trimester of pregnancy and the relationship to birth outcomes. Proc Nutr Soc. 2002;61:133A.

22. Kim NK, Choi YK, Kang MS, Choi DH, Cha SH, An MO, et al. Influence of combined methylenetetrahydrofolate reductase (MTHFR) and thymidylate synthase enhancer region (TSER) polymorphisms to plasma homocysteine levels in Korean patients with recurrent spontaneous abortion. Thromb Res. 2006; 117(6):653-8.

23. Alfthan $G$, Laurinen MS, Valsta LM, Pastinen T, Aro A. Folate intake, plasma folate and homocysteine status in a random Finnish population. Eur J Clin Nutr. 2003;57(1):81-8.

24. Papoutsakis C, Yiannakouris N, Manios Y, Papaconstantinou E, Magkos F, Schulpis KH, et al. The effect of MTHFR(C677T) genotype on plasma homocysteine concentrations in healthy children is influenced by gender. Eur J Clin Nutr. 2006;60(2):155-62.

25. Pihusch R, Buchholz T, Lohse $P$, Rübsamen $H$, Rogenhofer $N$, Hasbargen $U$, et al. Thrombophilic gene mutations and recurrent spontaneous abortion: prothrombin mutation increases the risk in the first trimester. Am J Reprod Immunol. 2001;46(2):124-31.

26. Kim JH, Jeon YJ, Lee BE, Kang $H$, Shin JE, Choi DH, et al. Association of methionine synthase and thymidylate synthase genetic polymorphisms with idiopathic recurrent pregnancy loss. Fertil Steril. 2013;99(6):1674-80. 